\title{
To Assess the Nutritional Quality of Triticale Based Product Medicated and Non-Medicated Health Powder
}

\author{
Seema Sonkar ${ }^{1}$, Shraddha Yadav², Rishi Bhel ${ }^{3} \&$ O. P. Bishnoi ${ }^{4}$ \\ ${ }^{1}$ Assistant professor, Food Science and Nutrition Department, Chandra Shekhar Azad University of Agriculture \\ and Technology, 208002, India \\ ${ }^{2}$ M.sc Food Science and Nutrition Department, Chandra Shekhar Azad and University of Agriculture and \\ Technology, 208002, India \\ ${ }^{3}$ Department of Genetic and Plant Breeding, 208002, India \\ ${ }^{4}$ Department of Genetic and Plant Breeding, C.C.S.H. University, 208002, India \\ Correspondence: Seema Sonkar, Food Science and Nutrition Department, Chandra Shekhar Azad University of \\ Agriculture and Technology, 208002, India. E-mail: seema07csa@ gmail.com
}

Received: November 24, 2017 Accepted: December 15, 2017 Online Published: June 6, 2018

doi:10.5539/jfr.v7n4p120 URL: https://doi.org/10.5539/jfr.v7n4p120

\begin{abstract}
Triticale is a more recent development in the field of cereals, that is a man made cereals created by crossing wheat and rye, compared to oats and barley, which have long histories, triticale is between 40 and 50 years old. Triticale is hybrid of wheat (Triticum) and rye (Scale) first bread in laboratories during the late $19^{\text {th }}$ century in Scotland and Germany. When crossing wheat and rye, wheat is used the female parent and rye is the male parent. The resulting hybrid is sterile and must be treated with colchicines to induce polyoidy and thus the ability to reproduce itself. High quality grain, conditioning products with desirable properties and nutritional value, determines the use of triticale for consumption. Therefore, more and more attention is paid in triticale breeding for its quality, to obtain highly yielding, but also technologically advantageous varieties.

The aim of this research was to evaluate nutritional quality and sensory properties of triticale based product that are - Medicated Health Powder which are made from germinated grain triticale, wheat, pearl millet, Beet root ashwagandha, safed musli and steavia powder and Non- Medicated Health Powder which are made from germinated grain triticale, wheat, pearl millet, and steavia powder. The result of the nutritional analysis indicated that the nutritional composition of Medicated health powder are moisture -8.5 , ash -2.20 , protein- 6.59 and iron-1.82 gm. Non-Medicated health powder are moisture -8.7, ash -1.89 , protein- 6.36 and iron-1.71 gm. Regarding sensory properties, these products were evaluated on sensory parameters using nine point hedonic rating scale. Sensory score for Medicated Health Powder for appearance 9.0, texture 8.4 color 8.2, flavor 8.0 and overall acceptability is 9.0. and Non-Medicated Health Powder for appearance 9.0, texture 8.8 color 8.4, flavor 8.8 and overall acceptability is 9.0. A sensory quality of products (Medicated health powder and Non- medicated health powder) was monitored during storage and was found stable for 3 months. Medicated and Non- medicated health powder health powder is recommended for diabetic patients and in cronic heart disease.
\end{abstract}

Keywords: cereals and millets, ashwagandha, safed musli, steavia, germination, sensory evaluation, chemical analysis

\section{Introduction}

As the population growth rate increasing high in comparison to food production land is stable so food production rate has shortest value because of that there is lack of field family purpose which causes less food the requirements because of these reasons of India are struggle with malnutrition. So scientists make effort in this direction to avail the food for the growing population draw attention of the scientist towards innovation in the field of crop. Triticale is a more recent development in the field of cereals, that is a man made cereals created by crossing wheat and rye, compared to oats and barley, which have long histories, triticale is between 40 and 50 years old. Triticale is hybrid of wheat (Triticum) and rye (Scale) first bread in laboratories during the late $19^{\text {th }}$ century in Scotland and Germany. When crossing wheat and rye, wheat is used the female parent and rye is the male parent. The resulting hybrid is sterile and must be treated with colchicines to induce polyoidy and thus the 
ability to reproduce itself.

The second area of interest for triticale grain is in developing it as a food grain cereal that would exhibit unique baking traits. As a food grain, triticale has also been recognized as a hardy crop capable of helping combat world hunger. Triticale has potential in the production of bread and other food products such as pasta and breakfast cereals Pena (2004).

Pearl millet (Pennisetum glaucum (L.) R. Br.) also known as bulrush or cattail millet is an important grain and forage crop in Africa and South Asia and a forage crop in the Americas. It is mostly grown under hot, dry conditions on infertile soils of low water-holding capacity, where other crops generally fail.

Millets are major food sources in arid and semiarid region of the world, and feature in the traditional cuisine of many others. It as birdseed, but it's not just for the birds! Millet is a delicious nutritious grain that can accompany many types of food. In addition to their nutritive value, several potential health benefits such as delaying gastric emptying, supplying gastrointestinal bulk preventing cancer, cardiovascular diseases, reducing tumor incidence, lowering blood pressure, risk of heart disease, cholesterol and rate of fat absorption have been reported for pearl millet (Gupta and Nagar, 2010).

Germination is the process by which the embryo wakes up from the state of dormancy and takes to active life. This process, in fact, covers all the change from the earliest sprouting of the seed till established itself as an independent plant. A mature seed is living but the embryo remains dormant. The seed then contains only 10 percent to 15 percent of water, and this low water content is one of the factors responsible for dormancy, when certain external conditions are satisfied the dormant embryo begins to grow. Germination is usually the growth of a plant contained with a seed. Germination is usually the growth of plant contained within a seed; it results in the formation of the seedling. It is also the process of reactivation of metabolic machinery of the seed resulting in the emergence of radical and plumule. Seed germination depends on both internal and external conditions. The most important external factors include right or darkness. The seed germination is a mechanism, in which morphological and physiological alterations result in activation of the embryo. Before germination, seed absorbs water, resulting in the expansion and elongation of seed embryo. When the radical has grown out of the covering seed layers, the process of seed germination is completed. Hermann (2007).

The beetroot is the taproot portion of the beet plant, usually known in North America as the beet, also table beet, garden beet, red beet, or golden beet. It is one of several of the cultivated varieties of Beta vulgaris grown for their edible taproots and their leaves (called beet greens).

A large proportion of the commercial production is processed into boiled and sterilized beets or into pickles. In Eastern Europe beet soup, such as cold borscht, is a popular dish. Yellow-coloured beetroots are grown on a very small scale for home consumption (Grubben and Denton 2004).

Ashwagandha is considered to be one of the best rejuvenating agents in Ayurveda. Its roots, seeds and leaves are used in Ayurvedic and Unani medicines. Ashwagandha root drug finds an important place in treatment of rheumatic pain, inflammation of joints, nervous disorders and epilepsy. Dried roots are used as tonic for hiccup, cold, cough, female disorders, as a sedative, in care of senile debility, ulcers, etc. Leaves are applied for carbuncles, inflammation and swellings. Leaf juice is useful in conjunctivitis. Bark decoction is taken for asthma and applied locally to bed sores. Ashwagandha and its extracts a Ashwagandha has anti-inflammatory, anti-tumor, anti-stress, antioxidant, mind- boosting, immune-enhancing, and rejuvenating properties. Ashwagandha root has also been noted to have sex-enhancing properties. Ashwagandha is mentioned in the ancient Kama Sutra as an herb to be used for heightening sexual experience. Ashwagandha has the ability to restore sexual health and improve overall vitality while promoting a calm state of mind.

Safed Musli (Chlorophytum Borivilianum), also called White Musli, is a potent aphrodisiac and string adaptogenic herb used in ayurveda and herbal science. It is effective for improving male performance, inducing spermatogenesis and providing strength to the muscles.

Safed Musli is one of important herb in ayurveda, which provides all these benefits. Safed Musli is medicinal plant with little white flowers. It is a medicinal plant which is used to treat sexual weakness and impotency problems in males.

The tubers of chlorophytum borivilianum have been effectively used by Meena community of Rajasthan, India , against bone fracture, leucarrhea as well as male tonic (Meena and Rao 2010).

The scientific name for stevia is Stevia rebaudiana Bertoni and it is a member of the largest family of plants, Asteraceae which is also called the "sunflower family". There are 240 close relatives of stevia and they are all herbs or shrubs originating from the tropical and semi-tropical areas of North, Central and South America. The 
discovery of the sweetness of the stevia plant is attributed to an Italian-Swiss botanist, Dr. Moisés S. Bertoni, in 1901. However, researchers believe the use of the plant to sweeten medicines and foods by indigenous people dates prior to the arrival of the Spanish in the 16th century.

\section{Material and Method}

The study was conducted in the department of Food Science and Nutrition, M.A.B College of Home Science, Chandra Shekhar Azad Agriculture University and Technology, Kanpur.

\section{Procedure of Preparation}

first step of preparation of product cleaning and removal of non- edible particle of all samples, second step washing the seed for two times, third step sun drying five hours daily till moisture free fourth step grinding three times till find powder, fifth step sieving and last steps storage after sieving storage in air tight container.

\section{Beet Root}

Take a beet root then peel the beet root after removing the non- edible parts of beet root by the grater and after removing the moisture prepared sample keep in air tight container.

\section{Process of Germination}

\subsection{Triticale Germination}

Cleaning of dust and dirt particle from the triticale after removing the non- edible parts of triticale it has been soaked in water level should be $1 / 3$ the seed 24 hours at the room temperature then tie a muslin clothes for 48 hours and after the germination the seed was spread strainer steel tray for sundry till moisture the prepare the sample after removing the moisture and keep in the air tight container.

\subsection{Pearl Millet Germination}

Cleaning of dust and dirt particle from the pearl millet after removing the non- edible parts of pearl millet it has been soaked in water level should be $2 / 3$ to $1 / 3$ the seed for 21 to 24 hours at the room temperature then tie a muslin clothes for 48 hours and after the germination the seed was spread strainer steel tray for sundry till moisture the prepare the sample after removing the moisture and keep in air tight container.

\subsection{Wheat Germination}

Cleaning of dust and dirt particle from the wheat after removing the non- edible parts of wheat it has been soaked in water level should be $2 / 3$ to $1 / 3$ the seed $21-24$ hours at the room temperature then tie a muslin clothes for 48 hours and after the germination the seed was spread strainer steel tray for the prepare the sample after the removing the moisture and keep air tight container.

Development of the Product

Table 1. Preparation of Medicated Health Powder: - (in 100g)

\begin{tabular}{llll}
\hline Ingredients & T1 & T2 & T3 \\
\hline Germinated Triticale & 15 & 10 & 5 \\
\hline Germinated Wheat & 50 & 50 & 50 \\
\hline Germinated pearl millet & 15 & 20 & 25 \\
\hline Beet Root & 15 & 10 & 5 \\
\hline Steavia powder & 5 & 10 & 15 \\
\hline Aswagandha & 0.5 & 1 & 1.5 \\
\hline Safed musli & 0.5 & 1 & 1.5 \\
\hline
\end{tabular}

Procdure: In medicated health powder three treatments are prepare from the ingreadient germinated triticale, pearl milet, wheat, pearl millet, beet root, steavia, ashwagandha and safed musli powder in the ratio of T1 (15:,50:,15:,15:,0.5:,0.5:,0.5) T2 (10:,50:,20:,10:,10:,1.0:,1.0) T3 (0.5:,50:,25:,0.5:,15:1.5:,1.5) and following steps are followed in this procedure. 
Table 2. Preparation of Non-Medicated Health Powder: - (in 100g)

\begin{tabular}{llll}
\hline Ingredients & T1 & T2 & T3 \\
\hline Germinated Triticale & 15 & 10 & 5 \\
\hline Germinated Wheat & 50 & 50 & 50 \\
\hline Germinated pearl millet & 15 & 20 & 25 \\
\hline Beet Root & 15 & 10 & 5 \\
\hline Steavia powder & 5 & 10 & 15 \\
\hline
\end{tabular}

Procdure: In non- medicated health powder three treatments are prepare from the ingredients germinated triticale, pearl millet, wheat, pearl millet, beet root, steavia in the ratio of $\mathrm{T} 1(15:, 50:, 15:, 15:, 0.5) \mathrm{T} 2$ (10:,50:,20:,10:,10) T3 (0.5:,50:,25:,0.5:,15) and following steps are followed in this procedure.

\section{Nutritional Analysis of the developed products:}

Prepared samples of Triticale were chemically analyzed by the standardized procedure -

\section{1: Determination of Moisture:}

The moisture content in the sample was determined by Oven drying method (A.O.A.C 1970).

Principle: Sample is heated at specified temperature for specific period of time and the loss of weight is recorded as moisture content of the sample.

Procedure: Five gram samples were weighted in a clear weighted glass dish. The sample was placed in a hot air set at $70^{\circ} \mathrm{C}$ for 2 hours. The dish was removed from oven and placed in desiccators to cool and weighting was repeated until the difference between two successive weighting was not more than $0.0002 \mathrm{gm}$.

\section{Observation :}

Weight of sample $=\mathrm{W}$

Weight of dish + sample before drying $=\left(\mathrm{W}_{1}\right)$

Weight of dish + sample after drying $=\left(\mathrm{W}_{2}\right)$

\section{Calculation :}

Moisture content was calculated using the formula =

Weight of dish with sample before drying - moisture percentage

$=\frac{\text { Weight of dish with sample after drying } \times 100}{\text { Weight of sample }}$

$=\frac{(\mathrm{W} 1-\mathrm{W} 2) \times 100}{\mathrm{~W}}$

2 Total Ash: Ash content represent the total mineral present in a biological material, total ash content was determined by incineration of sample in a muffle furnace, at $550^{\circ} \mathrm{C}$ (A.O.A.C 1970).

Procedure: Sample material $(5 \mathrm{gm})$ obtained after moisture determination was taken in a clean, pre-weighted crucible dish (19 gm). After weighing the sample crucible dish was placed in muffle furnace to charcoal the sample then after coaling the dish it was place in muffle furnace at 450 degree celcius for 5 hours and then after next day of the weight of the dish then again keep it the muffle furnace at the same temperature for 5 hours at the same process at repeat 5 times tiil constant weight of the dish then constant weight divied by the pre- heat weight for the dish along with the sample.

\section{Observation:}

Weight of dish $=\mathrm{Wg}$

Weight of Sample $=\left(\mathrm{W}_{1}\right)$

Weight of dish + sample before ignation $=\mathrm{W}_{2}$

Weight of dish + sample after ignition $=\left(\mathrm{W}_{3}\right)$

Calculation: The difference in weight of sample and content is expressed as:-

Ash percentage 


$$
\begin{aligned}
& =\frac{\text { Weight of Ash } \times 100}{\text { Weight of Sample }} \\
& =\frac{(\mathrm{W} 3-\mathrm{W}) \times 100}{\mathrm{~W} 1-\mathrm{W}}
\end{aligned}
$$

Weight of sample $=$ weight of dish + sample after ignition - weight of dish.

3 Crude protein: Crude protein was determined by multiplying total $\mathrm{N}$ content in sample by the factor 6.25 . Total $\mathrm{N}$ content in sample was determined by micro-kjeldahl method was described By "Sadasivam and Manickam (1996)".

Procedure: $0.2 \mathrm{~g}$ powdered samples were accurately weighed on a piece of filter paper and transferred along with the filter paper to $100 \mathrm{ml}$ micro-kjeldahl digestion tube. $10 \mathrm{ml}$ Sulphuric acid and 50mg digestion mixture (Cuso4 $+\mathrm{K}_{2} \mathrm{So} 4$, (1:5)) was added to the digestion flask, and the sample was digested and the electric heater until the contents become colourless. The digest was diluted with small quantity of distilled water and transferred to the micro-kjeldahl distillations apparatus using successive small quantities of distilled water. $10 \mathrm{ml}$ of $40 \%$ $\mathrm{NAOH}$ solution was poured until the apparatus and ammonia was liberated by steam distillation for 10min.

Distilled ammonia was collected in $100 \mathrm{ml}$ conical flask containing $10 \mathrm{ml}, 2 \%$ of boric acid solution and few drops of mixed indicators $(0.2 \%$ solution of methyl red and $0.2 \%$ solution methylene blue in ethanol mixed ratio of $1: 1$ ) were added.

Boric acid containing ammonia was titrated against the N/10 standard HCL until the first appearance of Voilet colour the end point.

A reagent blank with filter paper (without sample), digestion mixture and concentrate $\mathrm{H}_{2} \mathrm{SO} 4$ was also run and the titration volume of the blank was subtracted from titration of volume of the sample.

\section{Observation:}

Normality of $\mathrm{HCL}=\mathrm{N}$

The titrable value of sample - titrate value of blank $=\mathrm{V}$

Weight of sample $=\mathrm{W}$

\section{Calculation:}

Percentage $\mathrm{N}$ in the sample was calcutaled using the formula:

Nitrogen percent $($ in $100 \mathrm{mg})=\frac{1.4 \mathrm{X} \mathrm{N} \mathrm{X} \mathrm{V} \times 100}{\mathrm{~W}}$

Protein percent $=$ Nitrogen percentage X 6.25

Iron:

\section{AAS method of Iron Estimation:}

\section{Principle}

The Fe in acid digest of plant samples can be determined with the help of atomic absorption spectrophotometer (AAS).

The AAS is based on the principle that atoms of metallic elements ( $\mathrm{Fe})$ which normally remain in ground state, under flame conditions, absorb energy when subjected to radiation of specific wavelength. The absorption of radiation is proportional to the concentration of atoms of that element. The absorption of radiation by the atoms is independent of the wavelength of absorption and temperature.

\section{Equipment and apparatus:}

- Spectrophotometers, conical flasks, volumetric flask, wash bottle, pipette, hot plate, whatman no.1 filter paper.

\section{Reagents:}

- Vanadate-molybdate regent: Prepare solution 'A' by dissolving $25 \mathrm{~g}$ of ammonium molybdate in about $400 \mathrm{ml}$ of warm water. Prepare solution 'B' separately by dissolving $1.25 \mathrm{~g}$ of ammonium metavanadate in about $300 \mathrm{ml}$ of warm (70C) water, cool at room temperature and add $250 \mathrm{ml}$ of 
concentrated HNO3 and cool against at room temperature. Now add solution 'A' to solution 'B' slowly with continuous stirring and dilute to one liter with distilled water.

- $6 \mathrm{~N}$ HCL solution: Dilute $517 \mathrm{ml}$ of concentrated HCL to one liter.

- 2,4 di- nitrophenol indicator, 2.5\% : Dissolve 2:5 g of 2,4 di-nitrophenol in $100 \mathrm{ml}$ of $95 \%$ ethanol.

- Ammonia solution.

- Preparation of standard curve: Dissolve $0.2195 \mathrm{~g}$ of dried KH2PO4 in water, acidifying with $25 \mathrm{ml}$ of 7N H2SO4 and dilute to 1 liter. This solution contains $50 \mathrm{ppm}$ P. from $50 \mathrm{ppm}$ standard P solution, take appropriate volumes to prepare working solutions of $0.05,0.1,0.2,0.3,0.4,0.8$ and 1.0 ppm. Develop the color in identical manner. Prepare standard curve by plotting $\mathrm{P}$ concentration on $\mathrm{X}$ - axis and absorbance on $\mathrm{Y}$ - axis on a graph paper.

\section{Procedure:}

\section{Digestion of Sample:}

Weight $0.5 \mathrm{~g}$ plant material in a 50 or $100 \mathrm{ml}$ conical flask. Add 10-15 ml of diacid mixture of HNO3 AND HCLO4 in a ratio of 4:1 or triacdic mixture of HNO3, HCLO4 and H2SO4 in a ratio of 10:3:1. Keep it for overnight. Keep on a hot plate and heat gently at first. Then heat more vigoursly until a clear colourless solution results or till white fumes cease to come out. Do not take it to dryness. Discontinue heating when the volume up to the mark bu adding distilled water. Filter it through whatman No. 1 filter paper and use for further analysis.

\section{Calculations:}

Weight of plant material taken $=0.5$

Volume made after digestion $=50 \mathrm{ml}$

Dilution factor $=50 / 0.5=100$ times

Concentration of $\mathrm{Fe}$ in plant sample $=\mathrm{M}$ x 100

Where $\mathrm{M}$ stands for the Fe concentration in aliquot as read from standard curve against the sample readings.

\section{Sensory Evaluation of Developed Products:}

The acceptability of triticale based Non-medicated health powder, Medicated health powder and Chapatti spread prepared by germinated triticale, pearl millet and wheat, was judged by a panel of judges. The panel was decided after a primary sensitivity test.

The nine point hedonic scale was used to evaluate the germinated products for over all acceptability of them. In this test, a scale with score was given to each panel member, on the basis of which they gave score for each attribute of the sample. The mention of grade and score.

The product was considered excellent if score 8 and above, very good if scored 7 to less than 8 , good if scores6 to 7 , fair scored 5 to 6 and poor if scored less then 5 .

\section{Statistical Analysis}

In order to study "Develop and evaluate the nutritional composition of product" made from Triticale" a laboratory experiment was conducted and required data were collected. Analysis of variance of these data was worked out on the basis of completely randomized design (chandal, 1995)

\section{Result and Discussion}

The proximate composition protein, moisture, iron and ash of product Medicated Health Powder) are shown in Table No 3.

Table 3. Mean score of Nutritive value of Medicated health powder (in per $100 \mathrm{gm}$ )

\begin{tabular}{lllll}
\hline Medicated Health powder & \multicolumn{4}{c}{ Nutrients } \\
\hline Treatment & Moisture & Ash & Protein & Iron \\
\hline T1 $(15 \%)$ & 8.5 & 2.20 & 6.59 & 1.82 \\
T2(10\%) & 8.4 & 2.00 & 6.56 & 1.45 \\
T3(5.0\%) & 8.2 & 1.02 & 6.43 & 1.45 \\
SE (diff) & 0.10 & 0.08 & 0.08 & 0.01 \\
CD (0.05) & 0.22 & 0.18 & NS & 0.02 \\
\hline
\end{tabular}

T1- Treatment 1 T2-Treatment 2 T3- Treatment 3 
Moisture: Table 1 Shows that the mean score of moisture content of $\mathrm{T} 1(15: 50: 15: 15: 5.0: 0.5: 0.5), \mathrm{T} 2(10: 50: 20: 10: 10: 1.0: 1.0), \mathrm{T} 3(5.0: 50: 25: 5.0: 15: 1.5: 1.5)$ that is the ratio of geminated triticale, wheat, pearl millet, beet root, stevia, ashwagandha and safed musli in Medicated were $8.5 \%$, $8.4 \%$ and $8.2 \%$ respectively.

Table indicate that treatment first (15:50:15:15:5.0:0.5:0.5) incorporated products was found significant with respect to moisture content in comparison to other incorporated product .It is concluded that T1 had highest moisture content than that of other two incorporated treatments.

Ash: Table 3 shows that the mean score of T1 (15:50:15:15:5.0:0.5:0.5), T2(10:50:20:10:10:1:1) and T3(5.0:50:25:5.0: 15:1.5:1.5) that is ratio of germinated triticale, wheat, pearl millet, root, stevia, ashwagandha and safed musli in Medicated were $2.20 \mathrm{gm}, 2.00 \mathrm{gm}$ and 1.02.gm total ash content in per 100 gm respectively.

Table indicate that treatment first (15:50:15:15:5:.5:.5) incorporated products was found significant with respect to total ash content in comparison to other incorporated product .The total ash content of $\mathrm{T} 1$ incorporated product was better than other products.

Protein: Table 3 express that the mean score of $\mathrm{T} 1$ (15:50:15:15:5.0:0.5:0.5),T2(10:50:20:10:10:1.0:1.0)andT3(5.0:50:25:5.0:15:1.5:1.5) that is ratio of germinated triticale wheat, pearl millet, beet root, stevia, ashwagandha and safed musli in medicated were $6.59 \mathrm{gm}, 6.56 \mathrm{gm}$ and $6.39 \mathrm{gm}$ protein in per $100 \mathrm{gm}$ respectively.

Table shows that treatment first (15:50:15:15:5.0:0.5:0.5) incorporated products was found significant with respect to the protein content in comparison to other incorporated product .The protein content of $\mathrm{T} 1$ incorporated product was better than other products.

Iron: Table 3 express that the mean score of $\mathrm{T} 1$ (15:50:15:15:5.0:0.5:0.5), T2(10:50:20:10:10:1.0:1.0) and T3(5.0:50:25:5.0:15:1.5:1.5) that is ratio of germinated triticale, wheat, pearl millet, beet root, stevia, ashwagandha and safed musli in medicated were $2.31 \mathrm{gm}, 2.29 \mathrm{gm}$ and $2.28 \mathrm{gm}$ protein in per $100 \mathrm{gm}$ respectively.

Table indicate that treatment first (15:50:15:15:5.0:0.5:0.5) incorporated products was found significant with respect to iron content in comparison to other incorporated product . The total iron content of T1 incorporated product was better than other products.

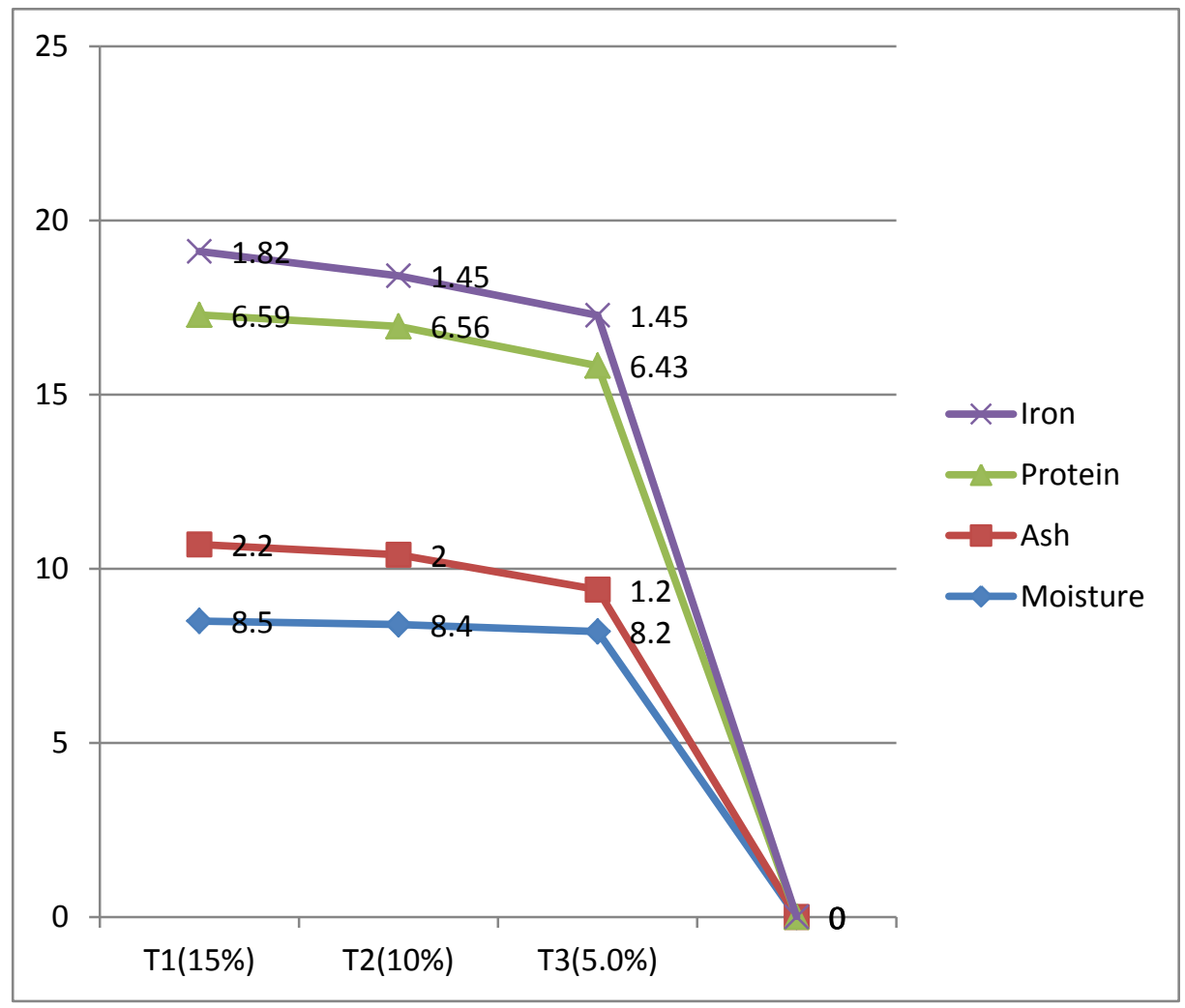

Figure 1. 
The proximate composition protein, moisture, iron and ash of product Medicated Health Powder) are shown in Table No 4.

Table 4. Mean score of Nutritive value of Non- medicated health powder (in per $100 \mathrm{gm}$ )

\begin{tabular}{lllll}
\hline Non- medicated health powder & \multicolumn{4}{c}{ Nutrients } \\
\hline Treatment & Moisture & Ash & Protein & Iron \\
\hline T1 $(15 \%)$ & 8.7 & 1.89 & 6.36 & 1.71 \\
\hline T2(10\%) & 8.6 & 1.82 & 6.23 & 1.25 \\
\hline T3(5.0\%) & 8.4 & 1.76 & 6.13 & 1.21 \\
\hline SE (diff) & 0.10 & 0.01 & 0.01 & 0.01 \\
\hline CD $(0.05)$ & 0.22 & 0.02 & 0.02 & 0.02 \\
\hline
\end{tabular}

T1- Treatment $1 \quad$ T2-Treatment 2 T3- Treatment 3

Moisture : Table 4 Shows that the mean score of moisture content of T1(15:50:15:15:5.0),T2(10:50:20:10:10) and T3(5:50:25:5.0:15) that is the ratio of geminated triticale, wheat, pearl millet, beet root and stevia in Nonmedicated were $8.7 \%, 8.6 \%$ and $8.4 \%$ respectively.

Table indicate that treatment first (15:50:15:15:5.0) incorporated products was found significant with respect to moisture content in comparison to other incorporated product .It is concluded that T1 had highest moisture content than that of other two incorporated treatments.

Ash: Table 4 shows that the mean score of T1 (15:50:15:15:5.0), T2(10:50:20:10:10) and T3(5.0:50:25:5.0:15) that is ratio of germinated triticale, wheat, pearl millet, beet root and stevia in Non- medicated were $1.89 \mathrm{gm}, 1.82$ $\mathrm{gm}$ and $1.76 \mathrm{gm}$ total ash content in per $100 \mathrm{gm}$ respectively .

Table indicate that treatment first (15:50:15:15:5.0) incorporated products was found significant with respect to total ash content in comparison to other incorporated product .The total ash content of $\mathrm{T} 1$ incorporated product was better than other products.

Protein: Table 4 express that the mean score of T1 (15:50:15:15:5.0), T2(10:50:20:10:10) and T3(5.0:50:25:5.0:15) that is ratio of germinated triticale, wheat, pearl millet, beet root and stevia in Nonmedicated were $6.36 \mathrm{gm}, 6.23 \mathrm{gm}$ and $6.13 \mathrm{gm}$ protein in per $100 \mathrm{gm}$ respectively.

Table shows that treatment first (15:50:15:15:5.0) incorporated products was found significant with respect to the protein content in comparison to other incorporated product . The protein content of $\mathrm{T} 1$ incorporated product was better than other products.

Iron: Table 4 express that the mean score of T1(15:50:15:15:5.0), T2(10:50:20:10:10) and T3(5.0:50:25:5.0:15) that is ratio of germinated triticale, wheat, pearl millet, beet root and stevia in Non- medicated were $2.37 \mathrm{gm}, 2.25$ $\mathrm{gm}$ and $2.26 \mathrm{gm}$ protein in per $100 \mathrm{gm}$ respectively.

Table indicate that treatment first (15:50:15:15:5.0) incorporated products was found significant with respect to iron content in comparison to other incorporated product. The total iron content of $\mathrm{T} 1$ incorporated product was better than other product 


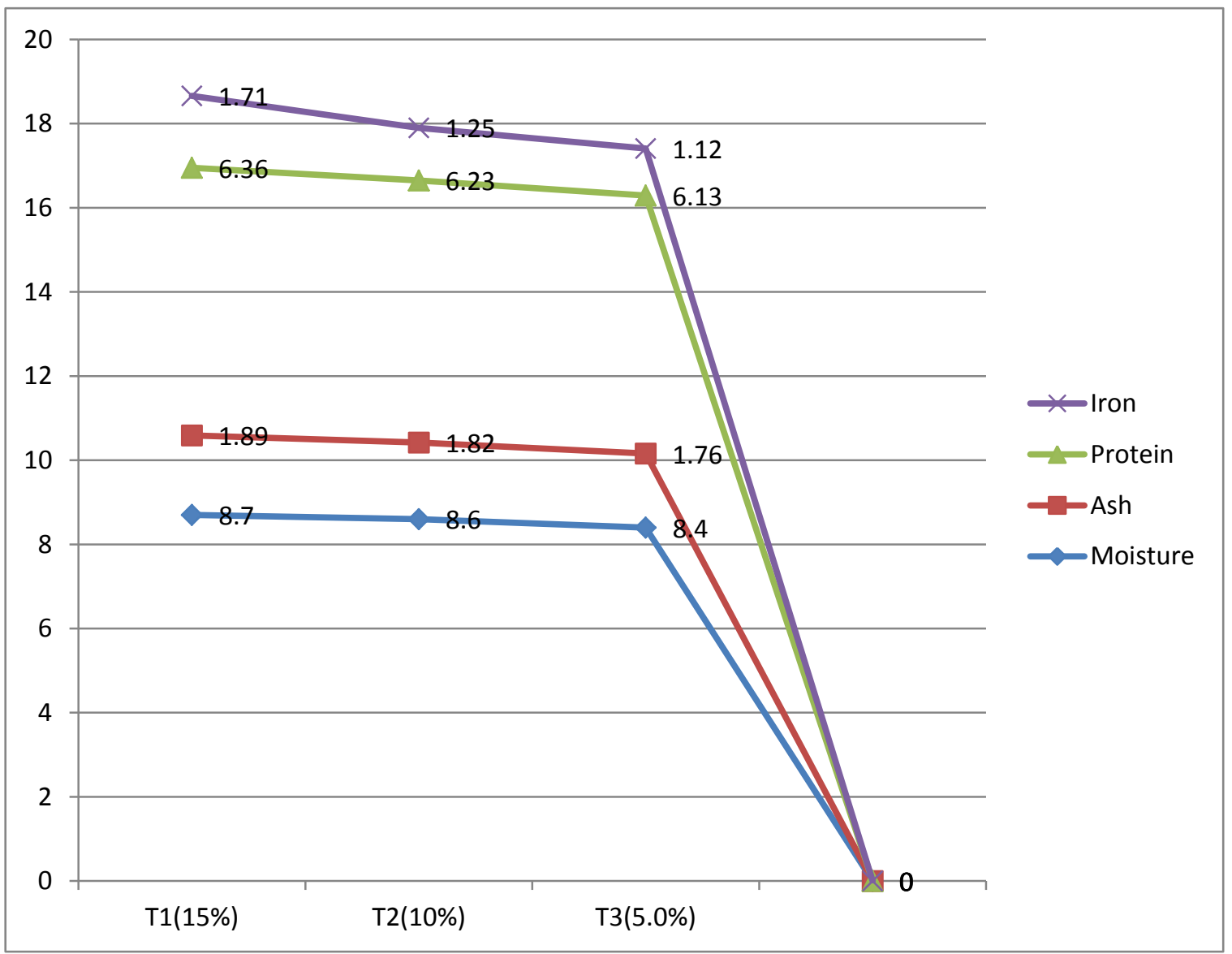

Figure 2.

Table 5. Mean score of organoleptic acceptability of Medicated health powder

\begin{tabular}{llllll}
\hline Parameters & \multicolumn{5}{l}{ Sensory Evaluation Attributes } \\
\hline Treatment & Appearance & Texture & Colour & Flavour & Overall acceptability \\
\hline T1 $(15 \%)$ & 9.0 & 8.4 & 8.2 & 8.0 & 9.0 \\
\hline T2 $(10 \%)$ & 8.4 & 7.4 & 7.8 & 6.8 & 8.2 \\
\hline T3(5\%) & 7.2 & 6.6 & 6.4 & 6.0 & 6.8 \\
\hline SE (diff) & 0.26 & 0.35 & 0.30 & 0.31 & 0.35 \\
\hline CD $(0.05)$ & 0.57 & 0.75 & 0.66 & 0.67 & 0.75 \\
\hline
\end{tabular}

T1- Treatment $1 \quad$ T2-Treatment 2 T3- Treatment 3

Appearance: Table 5 shows that the mean score of T1(15:50:15:15:5.0:0.5:0.5), T2(10:50:20:10:10:1.0:1.0) and T3(5.0:50:25: 5.0:15:1.5:1.5) that is the ratio of germinated triticale, wheat, pearl millet, beetroot, stevia, ashwagangha and safed musli in Medicated were 9.0,8.4and 7.2 respectively .

The above table shows that incorporated sample were significant at the $5 \%$ in critical difference. It means appearance of medicated were different from each other but the mean value of treatment first (15:50:15:15:5.0:0.5:0.5) incorporated sample was higher than other incorporated products.

Texture: Table 5 shows that mean score of T1(15:50:15:15:5.0:0.5:0.5), T2(10:50:20:10:10:1.0:1.0) and T3(5.0:50:25: 5.0:15:1.5:1.5) that is the ratio of germinated triticale, wheat, pearl millet, beetroot, stevia, ashwagandha and safed musli in Medicated were 8.4, 7.4, and 6.6 respectively.

The results reveal that incorporated products were significant at the level of $5 \%$ in critical difference. It means the texture were different from each other. The mean score of treatment first (T1) incorporated products was highest and treatment third (T3) incorporated was lowest. 
Color: Table 5 indicates that the mean score of T1 (15:50:15:15:5.0:0.5:0.5), T2(10:50:20:10:10:1.0:1.0) and T3(5.0:50:25: 5.0:15:1.5:1.5) that is the ratio of germinated triticale, wheat, pearl mille,t beetroot, stevia, ashwagandha and safed musli in Medicated were 8.2,7.8 and 6.4 respectively.

It is evident from the table that incorporated sample were significant at the level of $5 \%$ in critical difference which means the color were different from each other the mean score of treatment first (15:50:15:15:5.0:0.5:0.5), incorporated sample was better than other incorporated products.

Flavour: Table 5 indicates that the mean score of T1 (10:50:15:15:5.0:0.5:0.5), T2(10:50:20:10:10:1.0:1.0) and T3(5.0:50:25: 5.0:15:1.5:1.5) that is the ratio of germinated triticale, wheat, pearl millet, beetroot, stevia, ashwagandha and safed musli in Medicated were 8.0,6.8 and 6.0.

The above table shows that incorporated products were highly significant at the level of $5 \%$ in critical difference that means flavor were different from each other. The mean score of incorporated products treatment first (10:50:15:15:5:.5:.5) was better than other incorporated products.

Overall acceptability: Table 5 Indicates that the mean score of $\mathrm{T} 1$ (10:50:15:15:5.0:0.5:0.5), $\mathrm{T} 2(10: 50: 20: 10: 10: 1.0: 1.0)$ and T3(5.0:50:25: 5.0:15:1.5:1.5) that is the ratio of germinated triticale, wheat, pearl millet, beetroot, stevia, ashwagandha and safed musli in Medicated were 9.0,8.2and 6.8.

It is evident from the table incorporated sample were significant at the level of $5 \%$ in critical difference .which means overall acceptability were different from each other the mean score of T1 (10:50:15:15:5.0:0.5:0.5) incorporated products was highest than other incorporated products.

Table 6. Mean score of organoleptic acceptability of Non-medicated health powder

\begin{tabular}{llllll}
\hline 43Parameters & \multicolumn{5}{l}{ Sensory Evaluation Attributes } \\
\hline Treatment & Appearance & Texture & Colour & Flavour & Overall acceptability \\
\hline T1(15\%) & 9.0 & 8.8 & 8.4 & 8.8 & 9.0 \\
\hline $\mathrm{T} 2(10 \%)$ & 8.2 & 7.8 & 7.6 & 7.8 & 8.4 \\
\hline $\mathrm{T} 3(5 \%)$ & 7.4 & 6.8 & 7.2 & 6.6 & 7.0 \\
\hline SE (diff) & 0.26 & 0.38 & 0.49 & 0.40 & 0.33 \\
\hline CD $(0.05)$ & 0.57 & 0.84 & NS & 0.87 & 0.71 \\
\hline
\end{tabular}

T1- Treatment $1 \quad$ T2-Treatment 2 T3- Treatment 3

Appearance: Table 6 shows that the mean score of T1(15:50:15:15:5.0), T2(10:50:20:10:10) and T3(5.0:50:25:5.0:15) that is the ratio of germinated triticale, wheat, pearl millet, beetroot and stevia in Nonmedicated were 9.0,8.2 and 7.4 respectively .

The above table shows that incorporated sample were significant at the $5 \%$ in critical difference. It means appearance of non- medicated were different from each other but the mean value of treatment first (15:50:15:15:5.0) incorporated sample was higher than other incorporated products.

Texture: Table 6 shows that mean score of T1 (15:50:15:15:5.0), T2(10:50:20:10:10) and T3(5.0:50:25:5.0:15) that is the ratio of germinated triticale, wheat, pearl millet, beetroot and stevia in Non- medicated were 8.8, 7.8, and 6.8 respectively.

The results reveal that incorporated products were significant at the level of 5\% in critical difference. It means the texture were different from each other. The mean score of treatment first (T1) incorporated products was highest and treatment third (T3) incorporated was lowest.

Color: Table 6 indicates that the mean score of T1 (15:50:15:15:5.0), T2(10:50:20:10:10) and T3(5.0:50:25:5.0:15) that is the ratio of germinated triticale, wheat, pearl millet, beetroot and stevia in Nonmedicated were 8.4,7.6 and 7.2 respectively.

It is evident from the table that incorporated sample were significant at the level of 5\% in critical difference which means the color were different from each other the mean score of treatment first (15:50:15:15:5.0), incorporated sample was better than other incorporated products.

Flavour: Table 6 indicates that the mean score of T1 (15:50:15:15:5.0), T2(10:50:20:10:10) and T3(5.0:50:25:5.0:15) that is the ratio of germinated triticale, wheat, pearl millet, beetroot and stevia in Nonmedicated were 8.8,7.8 and 6.6.

The above table shows that incorporated products were highly significant at the level of $5 \%$ in critical difference that means flavor were different from each other. The mean score of incorporated products treatment first 
(15:50:15:15:5.0) was better than other incorporated products.

Overall acceptability: Table 6 Indicates that the mean score of T1(15:50:15:15:5.0), T2(10:50:20:10:10) and $\mathrm{T} 3(5: 50: 25: 5.0: 15)$ that is the ratio of germinated triticale, wheat, pearl millet, beetroot and stevia in Nonmedicated were 9.0,8.4and 7.0.

It is evident from the table incorporated sample were significant at the level of 5\% in critical difference .which means overall acceptability were different from each other the mean score of T1 (15:50:15:15:5.0) incorporated products was highest than other incorporated products.

\section{Conclusion}

Developed product have good composition of nutrients and as well as organoleptic qualities.

\section{References}

Brandle, J., \& Telmer, P. (2007). Steviol glycoside biosynthesis. Phytochemistry, vol. (68): pp. 1855-1863.

Grubben, G. J. H., \& Denton, O. A. (2004). International Journal of Food Science and Nutrition, 51(3), 195-208.

Hermann, K., Meinhard, J., Dobrev, P., Linkies, A., Pesek, B., Heß, B., Machackova, I., Fischer, U., \& Leubner-Metzger, G. (2007). A comparative study of fruits and seeds. J. Exp. Bot., 58, 3047-3060. https://doi.org/10.1093/jxb/erm162

Libby (2011). Beetroots have long been for medicinal purposes. International Journal purposes of Research in Ayueveda and Pharmacy, 3(5), 15-77

Meena, A. K., \& Rao, M. M. (2010). Falk herbal medicine used by meena community in Rajasthan. Asian Journal of Traditional Medicinal, 5, 19-31.

Pena, R. J. (2004). Food uses of triticale. In: Mergoum, M. and Go'mez-Macpherson H. (eds.). Food and Agriculture Organization of United Nations, Rome. 37-48.

Singh, N., Hoette, Y., \& Miller R. Tulsi (2010). 'The mother medicine of nature'. $2^{\text {nd }}$ edition. Lucknow: International Institute of Herbal Medicine. 28-32.

\section{Copyrights}

Copyright for this article is retained by the author(s), with first publication rights granted to the journal.

This is an open-access article distributed under the terms and conditions of the Creative Commons Attribution license (http://creativecommons.org/licenses/by/4.0/). 